\title{
Late Neolithic Agriculture in Temperate Europe-A Long-Term Experimental Approach
}

\author{
Manfred Rösch ${ }^{1, *}$, Harald Biester ${ }^{2}$, Arno Bogenrieder ${ }^{3}$, Eileen Eckmeier ${ }^{4}$, Otto Ehrmann ${ }^{5}$, \\ Renate Gerlach ${ }^{6}$, Mathias Hall ${ }^{7}$, Christoph Hartkopf-Fröder ${ }^{8}$, Ludger Herrmann ${ }^{9}$, Birgit Kury ${ }^{5}$, \\ Jutta Lechterbeck ${ }^{10}$, Wolfram Schier ${ }^{11}$ and Erhard Schulz ${ }^{12}$ \\ 1 Landesamt für Denkmalpflege im Regierungspräsidium Stuttgart, Fischersteig 9, \\ 78343 Gaienhofen-Hemmenhofen, Germany \\ 2 TU Braunschweig, Abt. Umweltgeochemie, Institut für Geoökologie, Langer Kamp 19c, \\ 38106 Braunschweig, Germany; h.biester@tu-bs.de \\ 3 Institut für Biologie/Geobotanik, Universität Freiburg, Schänzlestr. 1, 79104 Freiburg i. Br., Germany; \\ arno.bogenrieder@biologie.uni-freiburg.de \\ 4 Department für Geographie, Ludwig-Maximilians-Universität München, Luisenstraße 37, 80333 Munich, \\ Germany; e.eckmeier@geographie.uni-muenchen.de \\ 5 Büro für Bodenmikromorphologie und Bodenbiologie, Münster 12, 97993 Creglingen, Germany; \\ otto.ehrmann@gmx.de (O.E.); birgitkury@web.de (B.K.) \\ 6 Geographisches Institut Universität Köln, Albertus-Magnus-Platz, D-50923 Köln, Germany; r.gerlach@lvr.de \\ 7 Forstamt Hohenlohekreis, Stuttgarter Str. 21, 74653 Künzelsau, Germany; forstamt@hohenlohekreis.de \\ 8 Geologischer Dienst Nordrhein-Westfalen, Postfach 100763, 47707 Krefeld, Germany; \\ palaeontologie@gd.nrw.de \\ 9 Institut für Bodenkunde und Standortslehre, Universität Hohenheim, Emil-Wolff-Str. 27, 70593 Stuttgart, \\ Germany; herrmann@uni-hohenheim.de \\ 10 Arkeologisk Museum i Stavanger, Peder Klows gate 30A, 4010 Stavanger, Norway; lechter@gmx.de \\ 11 Institut für prähistorische Archäologie, Freie Universität Berlin, Fabeckstr. 23-25, 14195 Berlin, Germany; \\ wolfram.schier@topoi.org \\ 12 Institut für Geographie und Geologie, Universität Würzburg, Am Hubland, 97074 Würzburg, Germany; \\ erhard.schulz@mail.uni-wuerzburg.de \\ * Correspondence: manfred.roesch@rps.bwl.de; Tel.: +49-7735-93777-154
}

Academic Editors: Erle C. Ellis, Kees Klein Goldewijk, Navin Ramankutty and Laura Martin Received: 14 November 2016; Accepted: 24 January 2017; Published: 7 February 2017

\begin{abstract}
Long-term slash-and-burn experiments, when compared with intensive tillage without manuring, resulted in a huge data set relating to potential crop yields, depending on soil quality, crop type, and agricultural measures. Cultivation without manuring or fallow phases did not produce satisfying yields, and mono-season cropping on freshly cleared and burned plots resulted in rather high yields, comparable to those produced during modern industrial agriculture - at least ten-fold the ones estimated for the medieval period. Continuous cultivation on the same plot, using imported wood from adjacent areas as fuel, causes decreasing yields over several years. The high yield of the first harvest of a slash-and-burn agriculture is caused by nutrient input through the ash produced and mobilization from the organic matter of the topsoil, due to high soil temperatures during the burning process and higher topsoil temperatures due to the soil's black surface. The harvested crops are pure, without contamination of any weeds. Considering the amount of work required to fight weeds without burning, the slash-and-burn technique yields much better results than any other tested agricultural approach. Therefore, in dense woodland, without optimal soils and climate, slash-and-burn agriculture seems to be the best, if not the only, feasible method to start agriculture, for example, during the Late Neolithic, when agriculture expanded from the loess belt into landscapes less suitable for agriculture. Extensive and cultivation with manuring is more practical in an already-open landscape and with a denser population, but its efficiency in terms of the ratio of the manpower input to food output, is worse. Slash-and-burn agriculture is not only a
\end{abstract}


phenomenon of temperate European agriculture during the Neolithic, but played a major role in land-use in forested regions worldwide, creating anthromes on a huge spatial scale.

Keywords: Neolithic agriculture; experimental archaeology; slash-and-burn; temperate Europe

\section{Introduction}

After the domestication of plants in southwest Asia, which were adapted to a semi-arid climate and basic soils, several steps of the Neolithic colonization of temperate Europe can be recognized (Schier [1]). The last one in the late 5th and 4th Millennium BC took place in parts of Central and northern Europe, and the northern pre-Alpine lowlands. Agriculture requires open ground, and therefore, a clearing of natural woodlands is mandatory. The soil must be kept open by tillage or burning, to avoid reforestation. These measures have an effect on nutrient cycling, which can be influenced by manuring, nitrogen-fixing plants, and fallow systems. The most suited environments for agriculture in temperate Europe at that time, were regions with low annual precipitation (less than $500 \mathrm{~mm} \cdot$ year $^{-1}$ ), high summer temperatures, and fertile soils. These conditions define the settlement areas of the Linear Pottery culture (LBK) and of older Neolithic cultures in South-eastern and Southern Europe. In most parts of Central, Western, and Northern Europe, the conditions for agriculture were less suitable: average temperatures were lower and higher rainfall caused permanent nutrient loss via leaching.

The methods which Neolithic farmers could use was described by Bogaard [2]. LBK agriculture was based on small-scale hoe cultivation, the optimal method under the given ecological conditions (also Bogaard [2]). Whether systematic manuring was already in practice at this point in time, as Bogaard believes, is still debatable. Extensive ard cultivation is typical of younger periods since the Bronze Age, the evidence for which is provided by findings of ards and ardmarks, osteological characteristics of draft animals, and pollen profiles that suggest large open areas (cf. Bogaard [2]). Bogaard also mentions slash-and-burn techniques, as already discussed by Childe [3]. Slash-and-burn agriculture is the most simple cultivation system (Boserup [4]). Extensive ard cultivation was the favored model in Neolithic agriculture, as emphasized for more than 40 years (Sangmeister [5,6], Soudský [7]). The use of fire in Northern and Western Europe has also been discussed (Iversen [8,9], Smith [10]). Steensberg [11]) reports shifting cultivation experiments in Draved, Denmark. Because of their low yields, Rowley-Conwy [12]) does not consider this agricultural practice as one which was historically widespread.

A land use hypothesis for the Late Neolithic at Lake Constance included slash-and-burn practices (Rösch [13], Rösch, et al. [14]). An experimental approach was pursued in 1995, in order to compare slash-and-burn agriculture with other agricultural systems, for a discussion of the Neolithic (Rösch [15]; Bauer [16]). This paper aims to summarize the findings of these long-term experiments, including new results from 2016, and to respond to new publications which disagree on Neolithic land use and the practice of slash-and-burn agriculture.

\section{Material and Methods}

\subsection{Site and Experimental Design}

After three years of being situated in the open air museum of Wackershofen, close to Schwäbisch Hall, the experimental area moved to a forest of three hectares in size near Forchtenberg in 1998 that was provided for long-term use by the forest administration of Baden-Württemberg (Figure 1). The area is located on a gentle south-western slope (about $325 \mathrm{~m}$ a.s.l.), and prior to the experiments, was covered by a mixed deciduous forest of medium age trees (30-40 years old). The mean annual temperature is about $8.5{ }^{\circ} \mathrm{C}$ and the mean annual precipitation is about $900 \mathrm{~mm}$ (WaBoA [17]). According to 
old oak stumps and historical evidence, the place has been forested since at least 200 years ago. The area was divided into 34 plots of $30 \mathrm{~m} \times 30 \mathrm{~m}$. Every year, one plot was cleared and cultivated (Ehrmann, et al. [18]). Afterwards, a fallow phase of twelve years followed. In a few cases, annual cultivation for several years was practiced, with or without burning.

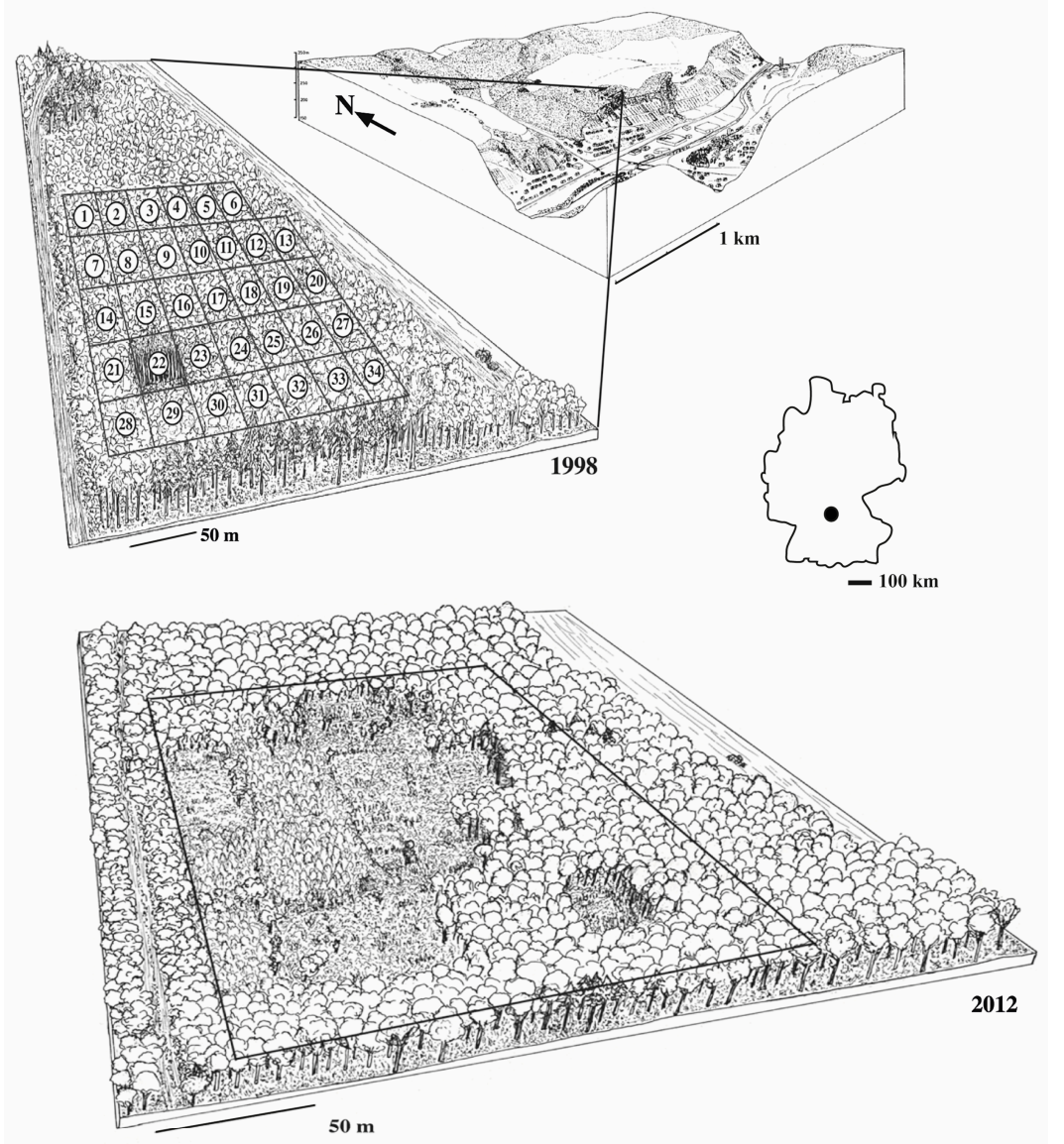

Figure 1. The regional setting of the experimental field in 1998 and 2012.

\subsection{Soils}

A more or less shallow (partly relocated) loess cover lies on top of the middle Triassic sedimentary rocks. Haplic and stagnic Luvisols, and their transitional forms, represent the most common soil reference groups in the cultivation area (FAO [19]), depending on the thickness of the loess cover. The granulometry shows little variation in silty textures, and frequent clay illuviation. However, topsoil $\mathrm{pH}$ values exhibit a certain variation, with a trend towards a lower $\mathrm{pH}$ (around 4) in the stagnic, and a higher $\mathrm{pH}$ (up to 5.5) in the haplic Luvisols (Herrmann [20]).

The water availability also differs. With respect to available water capacity, available nutrients, and nutrient stocks, the haplic are superior to the stagnic Luvisols. The available nutrient amounts are low. Further details, with respect to edaphic site conditions, are given by Herrmann [20].

\subsection{Agricultural Measures}

The trees were cut down during winter, partly by using replicas of Neolithic stone axes (Figure 2), and the trunks were removed. Ergometric data of more than 200 tree fellings were collected (Schier et al. [21], see Mathieu \& Meyer [22] for older felling experiments). A section of the plot was burnt in either the spring or the following autumn, using dry branches and twigs as fuel. Of the $900 \mathrm{~m}^{2}$ cleared area, 50-100 $\mathrm{m}^{2}$ was burned, consuming the weak wood of about half of the plot $\left(400-500 \mathrm{~m}^{2}\right)$. Burning was completed by pulling burning wood rolls slowly over the ground, in the 
style of the historical slash-and-burn ("Reutberg") agriculture of the Central European mountains (Schmithenner [23]; Schneiter [24]: Hafner [25]: Figure 3). Afterwards, the crops were sown in holes, and distributed in a regular pattern, resulting in a seed density of 320 grains $\cdot \mathrm{m}^{-2}$ or $120 \mathrm{~kg}$ seeds $\cdot \mathrm{ha}^{-1}$. Other seed densities resulted in a poor performance. Seed furrows or tillage were not practicable because of stumps, roots, and wood residues on the ground. Tillage was not necessary, since the soil was loose enough for direct sowing and as weed competition was absent, due to the burning process (cf. Boserup [4]: 24). For a more detailed description of the agricultural measures, see Ehrmann \& Rösch [26].

In the clearing, tillage without burning, partly by using replicas of Neolithic tools, but also modern iron hoes, was practiced. The tillage depth was $15 \mathrm{~cm}$; the size of the plots was between 1 and $10 \mathrm{~m}^{2}$.

Only large weeds like Cirsium were removed by hoeing or uprooting. In the burned plots, especially in the winter crops, weeds were rare (Ehrmann, et al. [18]).

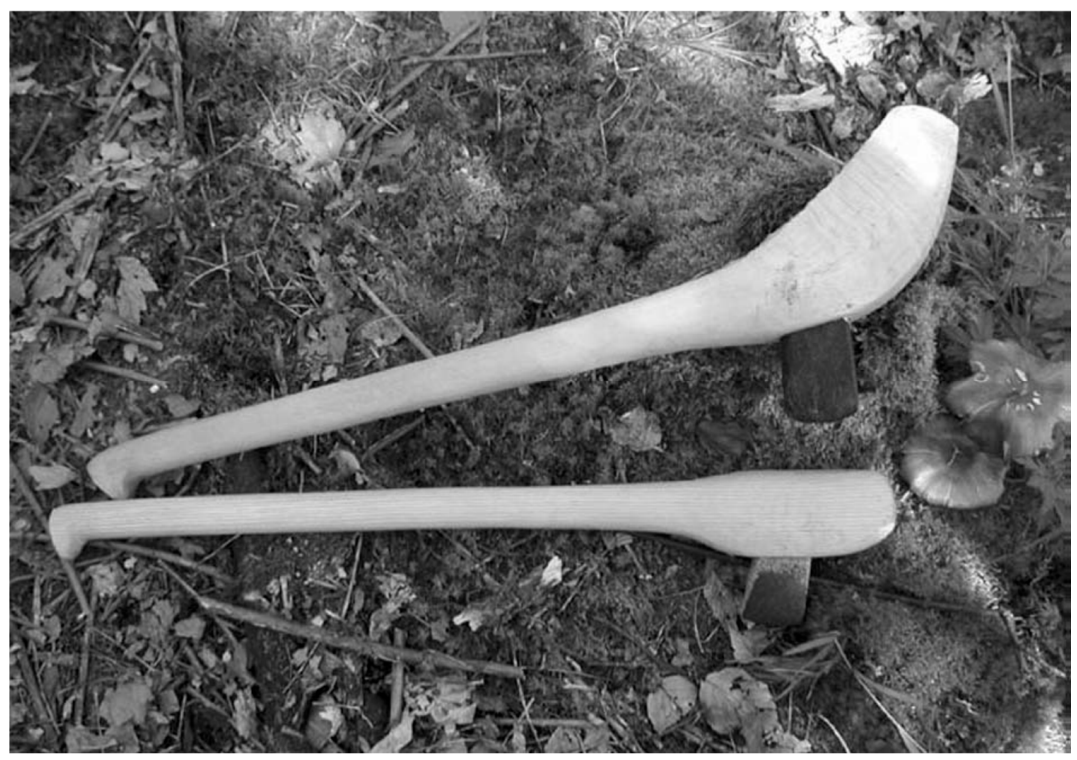

Figure 2. Functional replicas of Younger Neolithic stone axes shafted in straight and tangled shafts, produced by M. Kaiser, Freiburg.

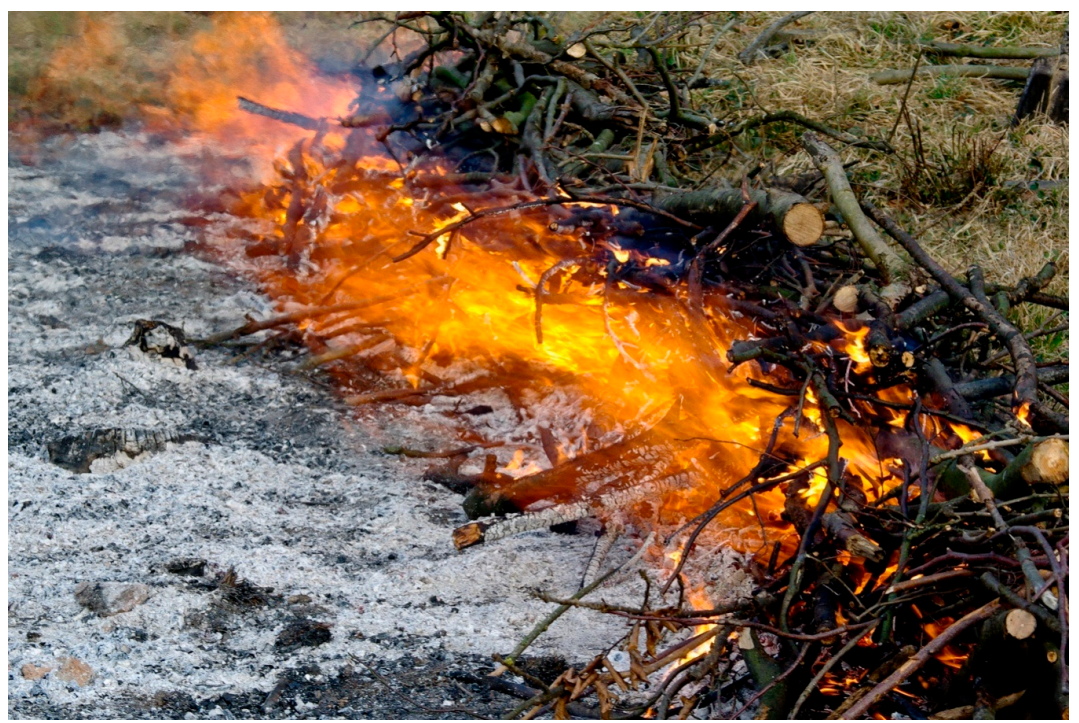

Figure 3. Burning by pulling burning wood cylinders, made of branches and twigs, over the ground (speed ca. $3 \mathrm{~m} \cdot \mathrm{h}^{-1}$ ). 


\subsection{Crop Species and Varieties}

All crops known from the Neolithic were grown. The autumn crops Triticum aestivum (old and modern varieties), Triticum dicoccon ("Schwarzer Winteremmer"), and Triticum monococum, were sown. The spring crops which were sown included Hordeum vulgare, old ("Nürnberger Probe" from 1832, Aufhammer \& Simon [27]) and modern varieties, Triticum durum, Triticum dicoccon, Triticum monococcum, and Triticum dicoccoides.

\subsection{Soil Nutrients}

In 2010/2011 a series of soil samples were collected before burning, and two collections of samples were collected from the haplic and the stagnic Luvisol plots after burning. Sampling depths were 0-2.5 cm, 2.5-5 cm, 5-10 cm, and 10-20 cm; each depth included five replications. The samples were stored in deep frozen conditions and then directly air dried, prior to analysis. Plant-available $\mathrm{P}$ and $\mathrm{K}$, as well as $\mathrm{N}_{\min }\left(\mathrm{NH}_{4}{ }^{+}+\mathrm{NO}_{3}{ }^{-}\right)$, were analyzed (Blume, et al. [28]). All nutrient concentrations are given on a dry weight basis. Water content was determined as the difference in weight after drying at $105^{\circ} \mathrm{C}$.

\section{Results}

\subsection{Clearing}

The felling time linearly increases with the trunk's cross sectional area (Schier, et al. [21], Figure 4): Several thin trees can be cut much more easily than a single thick tree. The tree species, workers' experience and skills, as well as the stone axe type, explain only $10 \%$ of the variance in the working time, when a multiple ANOVA test is applied to the data. A direct comparison between a 15-year old and a 50-year old forest plot shows that 4.9 working days were needed to clear 0.1 ha in the young, but 14.6 working days were required in the older forest, calculated on the basis of a regression equation.

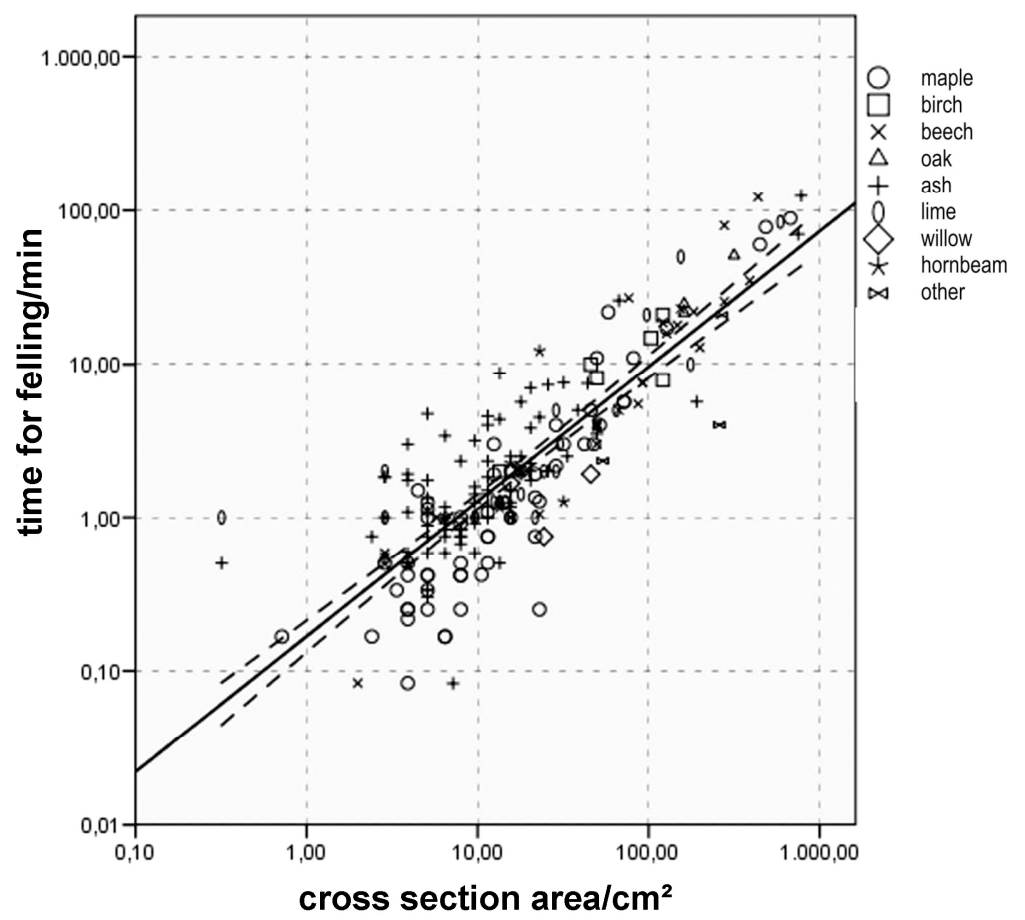

Figure 4. Regression diagram showing the time used for felling (x-axis, min) in relation to the cross section area of the trees $\left(\mathrm{y}\right.$-axis, $\mathrm{cm}^{2}$ ) and the tree species. Both scales are logarithmic. 


\subsection{Yields}

The cereal yield is determined by the number of ears per surface area, the number of grains per ear, and the average grain weight. These variables were determined during spring and depend on the nutrient supply, given sufficient water and light. In Forchtenberg, the N supply is the critical factor determining the yield (Ehrmann, et al. [29]). For a wheat yield of $50 \mathrm{dt} / \mathrm{ha}$, an amount of about $90 \mathrm{~kg} / \mathrm{ha}$ of $\mathrm{N}$ is consumed from the soil (KTBL [30]).

\subsubsection{Impacts of Agricultural Measures and Environmental Conditions on Yields}

(1) The Influence of Crop Species on Yields

Autumn-sown crops have higher yields than spring-sown crops. The crop type also influences the yield (Figure 5): in comparison with the old Triticum aestivum race, taken as a reference, the winter crops Triticum monococcum and dicoccon showed 60\% and 80\% yields, respectively. Among spring crops, wild Triticum dicoccoides produced a yield of about 30\%, T. monococcum, T. dicoccon, and T. durum produced a figure of $30 \%-40 \%$, and Hordeum vulgare (old/modern) produced a yield of $75 \%-90 \%$. The highest performance was recorded for the modern Triticum aestivum, which had a $28 \%$ higher yield than the old race.

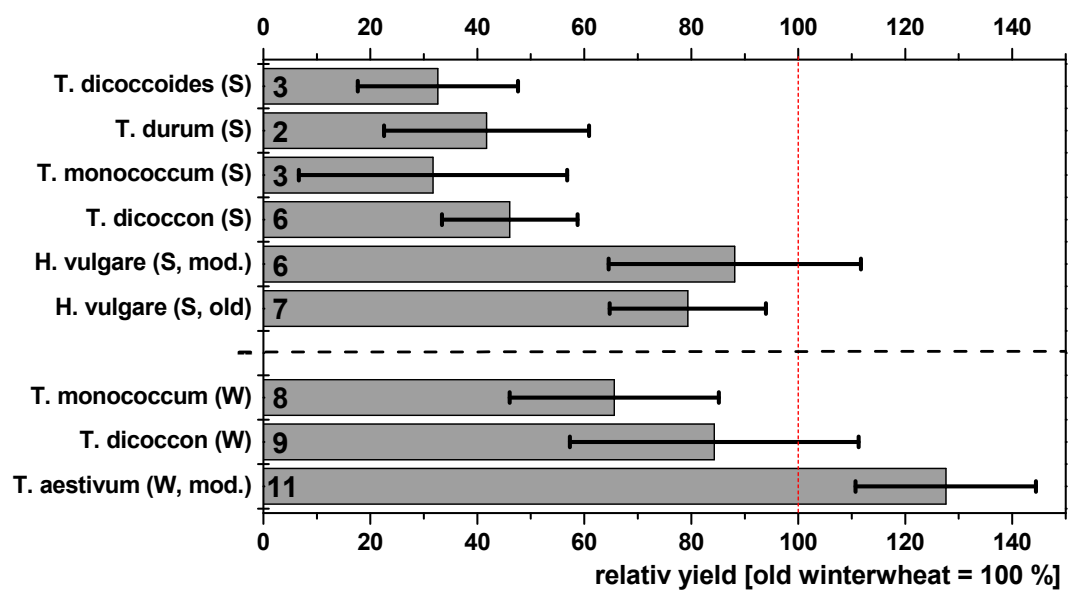

Figure 5. Relative average yields for various crop types, compared to the output of "old" winter wheats (Triticum aestivum, old) after burning, for the period 2000-2012. Not all crops were planted annually; the number of repeats is given at the beginning of each bar; S, summer; W, winter; mod, modern.

(2) The Influence of Soil Properties on Yields (After Burning)

The Triticum aestivum yields after burning are compared with the average yields in Baden-Württemberg (Figure 6). Before 2003, experiments were on stagnic, and later, they were mostly on haplic Luvisols. Yields on stagnic Luvisols were distinctly lower. Experiments using haplic Luvisols reached, and sometimes exceeded, the average yields of modern agriculture in Baden-Württemberg. 


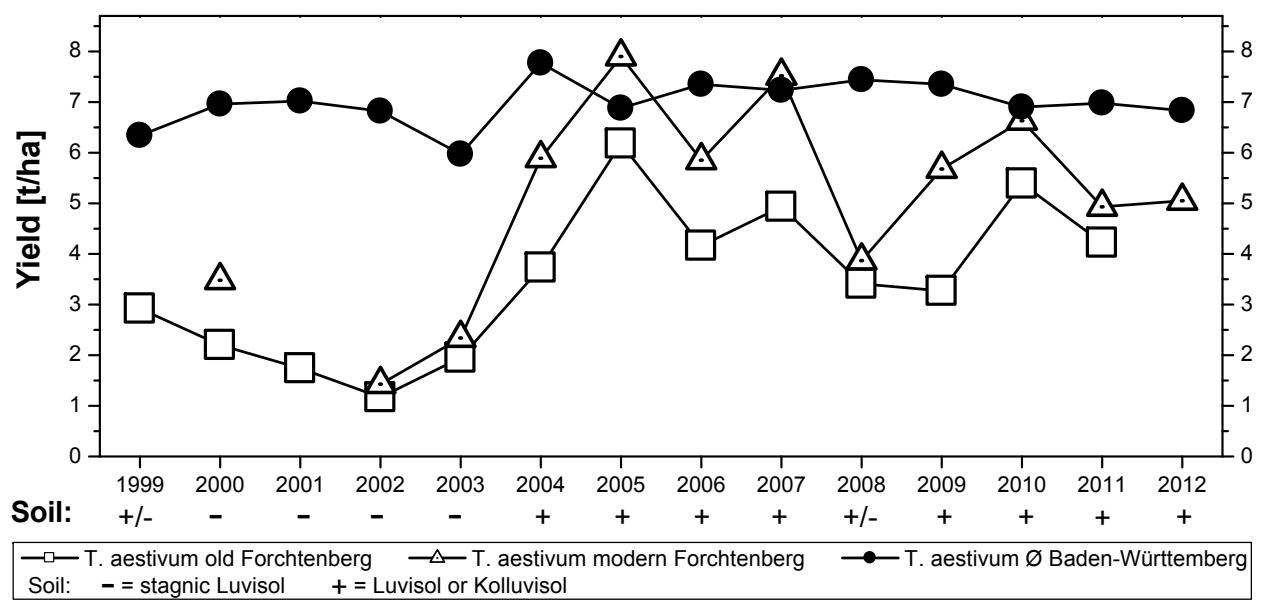

Figure 6. Triticum aestivum (winterwheat) yields after burning in Forchtenberg and long-term averages for modern agriculture in Baden-Württemberg (Bundesministerium für Ernährung, Landwirtschaft und Verbraucherschutz 2013) (Ehrmann, et al. [29]).

(3) The Influence of Soil Properties on Yields after Burning or Tillage

The average yield of all crops on the burned plots was between 1.8 and more than 5 tons $\cdot \mathrm{ha}^{-1}$, depending on the soil properties. The yields after tillage were much lower, producing a figure of $30 \%$ in the first year after clearing, and less than $10 \%$ in the following years, depending on whether the field was burned in the first year. With tillage, only the first year and the best soils led to reasonable yields. In all other cases, the yield was hardly above, or even below, the sowing amount.

Figure 7 shows the influence of soil quality and the growing method on the yield.

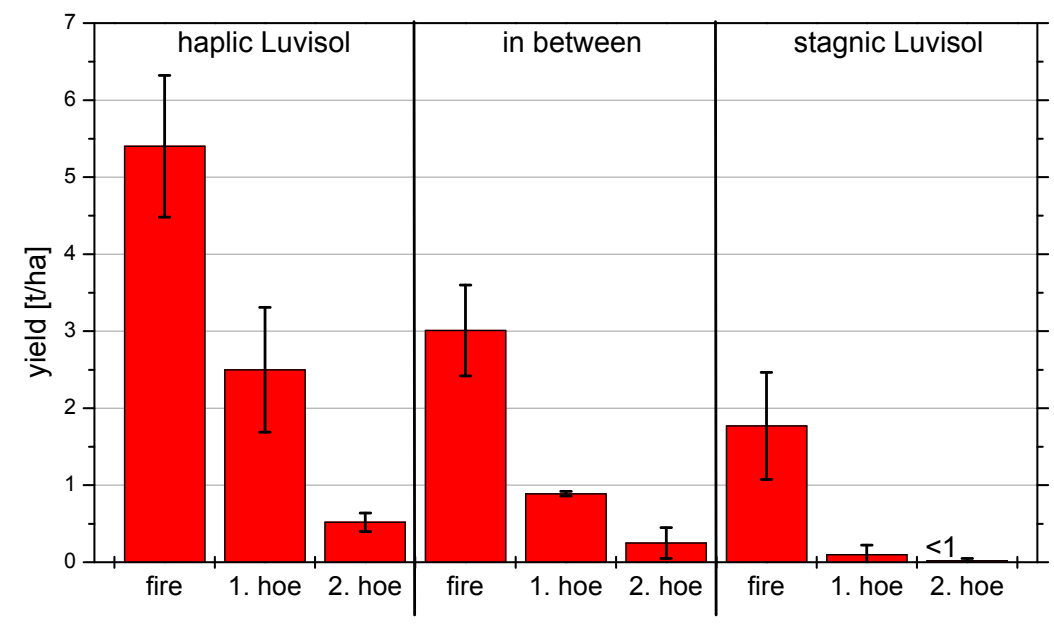

Figure 7. Crop yields. Mean values of Triticum aestivum (modern and old winter wheats) on different soils and with various cultivation methods (1998-2012) (Ehrmann, et al. [29]). Note: fire = first cultivation year after clearing and burning; 1 . hoe = tillage, first cultivation year after clearing; 2. hoe $=$ tillage, second and following cultivation years after clearing.

(4) A Combination of Burning and Tillage

From the tropical rain forest of South America, a cultivation system combining burning, tillage, and the application of organic matter is known, resulting in a soil called terra preta (Glaser, et al. [31]). Similar methods cannot be excluded for the European Neolithic. To get more experience of such a system, a test combining fire and tillage was carried out in 2016. The experiment took place on a plot with poor soil that was first cleared and cultivated in 1994. Because of too much rain, 2016 was a very 
difficult year for agriculture in South-west Germany. The results are shown in Figure 8. The yield after tillage, without the use of fire, was typically low. The yield after burning was about 24dt/ha, which is not so bad for stagnic Luvisol during a very wet year. The yield after burning and subsequent hoeing was exactly the same. In this very wet year, we had severe problems with mildew for the first time. The crops on the burnt and hoed field looked better, but were more easily infested by mildew than the crops on the burnt-only field. Therefore, the yield is the same. In order to obtain clearer results, these experiments should be continued.

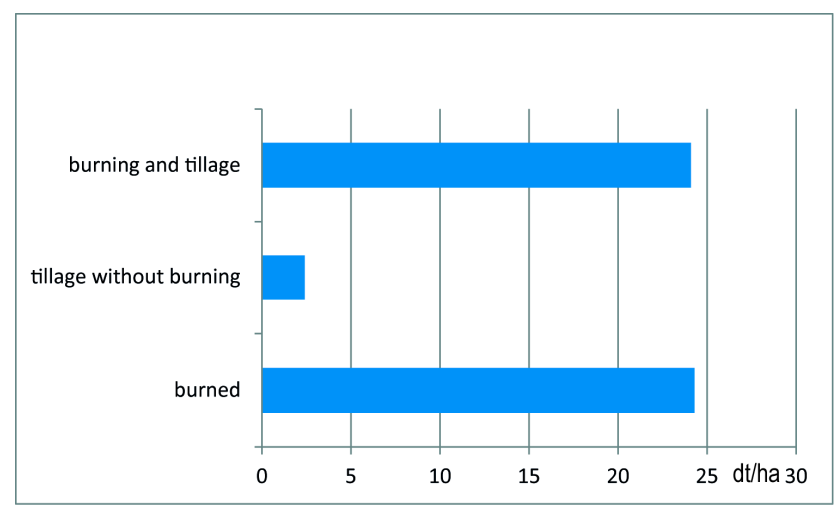

Figure 8. Yields of the year 2016 in Forchtenberg (dt/ha).

\subsubsection{Possible Processes that Cause the Differences of Yields}

(1) The Influence of Burning on $\mathrm{pH}$ and Available Nutrients

The ash produced by burning leads to an increased $\mathrm{pH}$ (about $2 \mathrm{pH}$ units) in the top few centimeters of the soil, resulting in neutral conditions. This particularly favors the growth of Hordeum and Triticum.

After burning, a strong increase in N, P, and K can be seen, all of which are available to the soil (Ehrmann, et al. [29]). With autumn burning, these minerals are partly lost until spring, due to leaching. The higher nutrient availability in the haplic Luvisol is not surprising, given the differences in the nutrient stocks (Herrmann [20]). For the major growing period in spring and early summer, no nutrient data are available. However, a second nutrient mobilization phase can be assumed in spring, with rising temperatures.

The black soil surface generates an important advantage, due to faster heating. Topsoil temperatures on burned plots can be up to $10^{\circ} \mathrm{C}$ higher than those in the surrounding area.

\section{(2) Origin of the Plant Nutrients}

In 2011, ash and charcoal were removed from half of the plots after burning, by raking and brushing. Since the yield (Figure 9) was not influenced, the available nutrients necessary for good crop growth cannot solely be derived from the burned biomass. In addition, an increase of the topsoil temperature, due to the thermal decomposition of organic matter and minerals, causes property of the topsoil to change, resulting in a good yield (Ehrmann \& Rösch [26]). High temperature also affects the microbial community, which is destroyed, and subsequently reorganizes to adapt to the new $\mathrm{pH}$-conditions (Herrmann, et al. [32]) before it can start to decompose organic materials for the delivery of new nutrients.

With tillage, nutrient mobilization is much weaker. In cleared, but not further treated areas, no nutrient mobilization is detectable. 


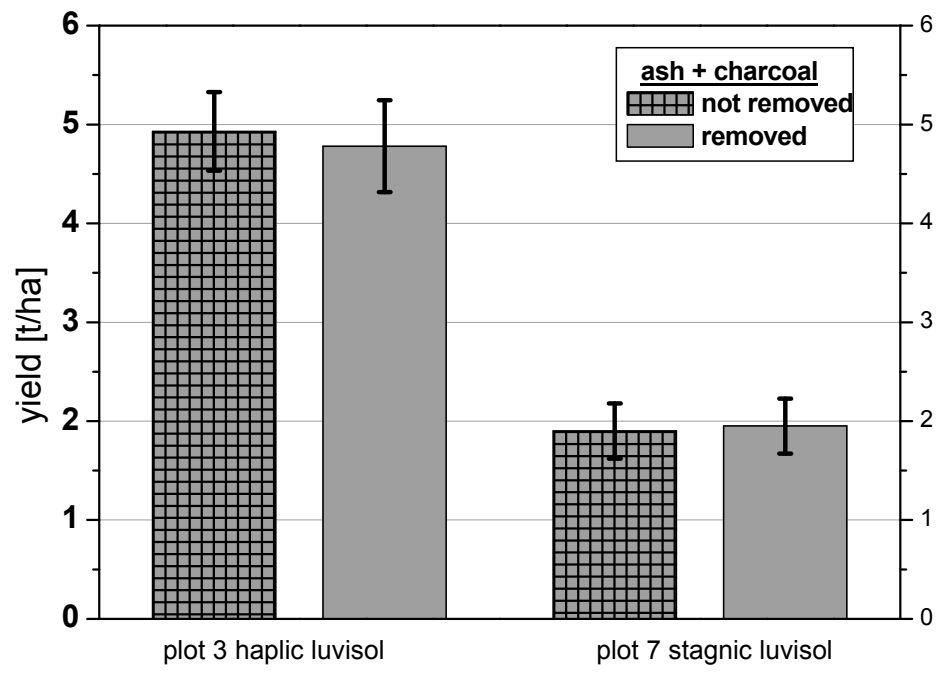

Figure 9. Crop yields ( $\mathrm{t} / \mathrm{ha}$ ) of Triticum aestivum (winter wheat, modern variety), with and without removal of charcoal and ash (Ehrmann, et al. [29]).

\subsection{Implications of the Properties of Slash and Burn Agriculture According to the Current Experimental Results}

\subsubsection{Permanent Cultivation with Burning?}

During the second half of the 4th Millennium B.C., in the Northern pre-Alpine lowlands, the agriculture changed, becoming more permanent. However, practices with burning continued (Jacomet [33]; Rösch, et al. [34]), perhaps by focusing slash-and-burn agriculture on fertile soils. Burning and cultivating the same field every year, using wood from nearby areas, resulted in decreasing yields in Forchtenberg, from the third year onwards (Figure 10).

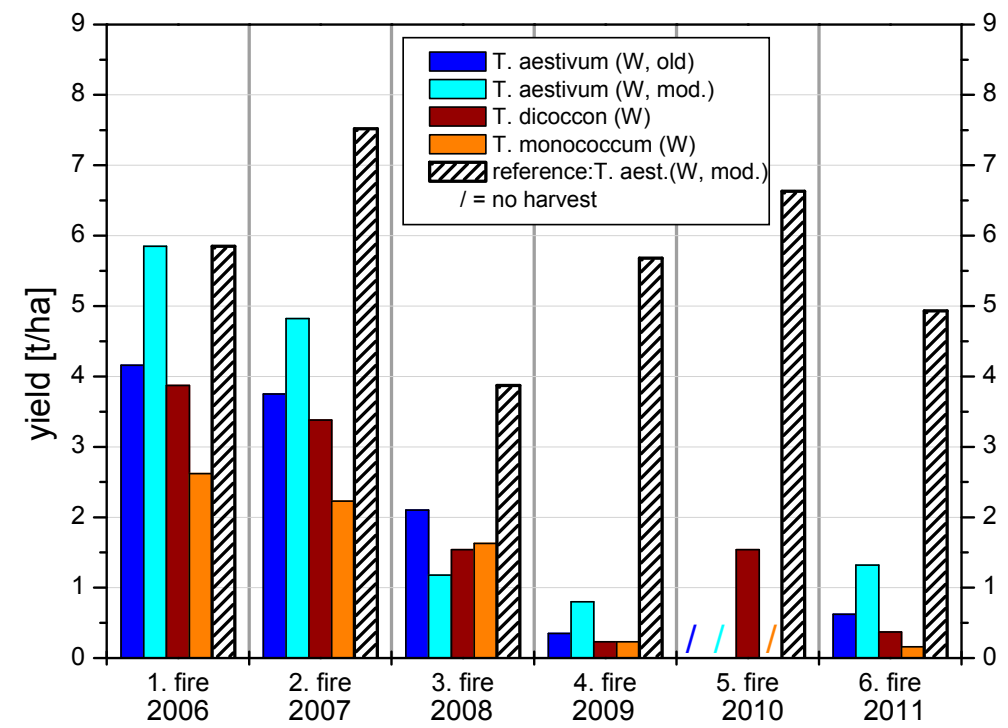

Figure 10. Development of crop yields following consecutive burning of the same area; W, winter; mod., modern (Ehrmann, et al. [29]).

A probable reason is the change of topsoil organic matter properties, degrading the easily mineralized fraction by repeated burning. Therefore, a modification of the slash-and-burn approach, towards a locally permanent cultivation, does not seem possible in such a simple way. A combination of long fallow phases with animal grazing, a kind of field-grass-system, with a restart of cultivation 
using the burning of imported wood, seems possible (in this context, a simple method without complex manuring techniques was thought of, but this requires further research).

\subsubsection{After the Harvest}

On abandoned fields, the succession back to a forest starts either by regeneration from the rootstocks, or by the germination of seeds (e.g., Betula pendula, Fraxinus excelsior, Salix caprea) sometimes with an intermediate ruderal/high herb stage (Schulz, et al. [35]). Finally, coppice will take over, and after 12 years, there is enough wooden biomass to burn again. The topsoil has accumulated humus to be mobilized by burning. Consequently, the cycle can continue. A second burning of the same field after 9 years resulted in even higher yields than those produced after the first burning.

The charcoal covering the soil surface after burning is later overgrown. Particles will be fragmented by frost and biotic action. When they are small enough, they will be browsed by earthworms, thereby becoming even smaller and being dislocated into deeper soil layers. The final fate of the charcoal still needs to be studied during long-term observations (Eckmeier, et al. [36]).

\subsubsection{A Preliminary Economic Balance}

An evaluation of all of the measures required to produce cereals, comparing different cultivation methods and soils, resulted in the following time requirements in working days, for the production of $400 \mathrm{~kg}$ of winter wheat; the working day was calculated as being eight hours. The following work processes were considered: felling, delimbing, tilling, burning, sowing, weeding, and harvesting. With the slash-and-burn method, 84 days are needed on rich soils, 127 days on medium, and 222 days on poor soils. For one-year cultivation and clearing without burning on rich soils, 189 days are necessary, on medium soils 475 days, on poor soils net yields were negative. Permanent cultivation with hand tillage and without fertilizer needs 650 days on rich soils and 2880 days on medium soils; on poor soils, net yields were negative. The complete table was published by Ehrmann, et al. [18]. Newer yield data suggest somewhat better results for cultivation without burning and permanent cultivation without manuring, but the overall result is not changed significantly.

\section{Discussion}

\subsection{Possible Reasons for Slash-and-Burn and Evidence in the Archaeological Record}

As people began to practice agriculture in increasingly northern latitudes, it had to adapt to changing environmental conditions, such as the average temperature, season distribution, rainfall-evapotranspiration ratio, and soil nutrient/organic matter stock.

In the Near East, and also in the Mediterranean, rather high seasonal soil temperatures favor the decomposition of easily mineralizable soil organic matter fractions (Mürle [37]), but water is limited during the warmer season. In Neolithic times, many soils of the temperate zones probably had a good organic matter and consequently $\mathrm{N}$ stock under the forest, due to high biomass production, but hampered decomposition during the cold season. A problem that Neolithic farmers had to deal with is the leaching of nutrients in spring, when the temperature rises and microbial organic matter decomposition outmatches plant growth and plant nutrient uptake.

To confine agriculture to regions with a dry and warm climate, and "good soils", was no permanent solution, because these areas are restricted and would have limited population growth. A possible solution could have been sophisticated agricultural systems of extensive ard cultivation, in combination with crop rotation, short fallow phases with animal browsing, and forest pasture, as well as organic manuring (a nutrient redistribution system according to Menke [38]). Such sophisticated systems require a lot of man and animal power, as well as a lot of agricultural skills and experience. Perhaps these refined systems were developed during the Trichterbecher culture (Kirleis \& Fischer [39]), but were not generally in use before the Bronze Age (cf. Bogaard [2]). 
The first farmers to cultivate the former glaciated landscapes of Central Europe faced a relatively wet climate and a completely forested area, with highly resilient vegetation. Slash-and-burn agriculture has been a tradition in many parts of temperate Europe, with dense forests and a rather wet and cold climate (Wilmanns, et al. [40]; Pott [41]; Nolte [42]; Jääts, et al. [43]). A decline in soil quality and yields after one Millennium of Linear Pottery and Middle Neolithic agriculture is very probable, and therefore the application of slash-and-burn techniques during the Michelsberg culture in the loess belt, is an option that must be taken into account (Kreuz, et al. [44]; Rösch, et al. [14]). Perhaps agricultural problems and innovations in the loess belt during the Michelsberg culture, preceded the colonization of the pre-Alpine lowlands by the Aichbühl, Schussenried, and Pfyn cultures.

In the pre-Alpine lowlands, slash-and-burn practices were applied from 4300 until 2300 B.C., for about two millennia. The evidence is given by micro-charcoal and cereal pollen in off-site pollen profiles, as well as by the decrease of Fagus and increase of Corylus and Betula. Outside the pre-Alpine lowlands, high-quality pollen records and therefore, off-site evidence, are lacking. On-site evidence is given by very clean unthreshed cereal stocks, without the crop weed seeds that are typical of later periods, and the important role of the very demanding Triticum durum/turgidum crops (Maier [45]).

\subsection{Implications of the Forchtenberg Results}

According to the Forchtenberg results, providing a sufficient N-supply for cereals is not an easy task, especially if the conditions are not optimal (like low soil-pH, high leaching rates, or low mobilization), but slash-and-burn is one tool which can be used in such production. No matter how one wishes to continue, the use of fire is beneficial if the woodland is colonized for the first time. Obviously, the first clearing of a primary forest is rather hard work, but the following burning constitutes much less work than hoeing the root felt of the forest. In the case of shifting cultivation, a fallowing period of about 10-15 years follows cropping. However, at least the clearing of coppiced forests is much easier than the first clearing of the primary forest.

The experiments derived data from LN Lake Constance, but the findings are not restricted to a specific time or area, and are generally applicable.

\subsection{State of Discussion about the Role of Slash-and-Burn}

Recently, these results and interpretation were emphatically contradicted (Jacomet, et al. [46], Baum, et al. [47]). Their ideas are mainly based on onsite data from Swiss lakeshore dwellings, thereby solely focusing on the Late Neolithic.

They acknowledge that the charcoal input in lake sediments in the Late Neolithic is higher than at any other period, but look for explanations other than cereal production. According to their opinion, the opening of the forest took place to create a more suitable landscape for animal browsing, gathering, and hunting. They ignore two facts: first, a successive opening of the landscape would have resulted in more NAP (non-aboreal pollen) input, which is clearly visible in the pollen profile from Mainau (Jacomet, et al. [46]), as in all other pollen records from the region from the EBA onwards, but not in the Late Neolithic; second, to burn a deciduous forest in temperate Europe, the trees must first be cut down and the wood must dry. This requires a lot of time and labor input, and it is therefore possible to create small fields, but not to create huge pastures and hunting landscapes. To open the canopy, the felling of trees would be the most important measure and browsing may keep an area open, but what could be the further benefits of burning? In other climates, layers of dead grass or other surface humus can hamper the growth of fresh grass, but on the Forchtenberg experimental site, there are no hints that burning changes the vegetation cover to considerably better grazing conditions.

There are several more ideas in this paper that could be tested experimentally, in order to test whether they are practicable. We agree with Jacomet, et al. [46]), that experimental proof of hypotheses dealing with the past is not possible. But, experiments can rule out ideas that just do not work, they show otherwise unknown hints or problems, they provide data that are indispensable 
for modelling approaches (see Baum 2014 [47], Baum, et al. 2016 [48]), and they provide material for further investigations, for example, isotope analysis.

Baum et al. (2016) combined a program for dynamics in agro-ecosystems, with another program that transfers the results into maps of the investigated area. Their approach shows that slash-and-burn resulted in the worst productivity of the tested methods. According to our own results, slash-and-burn should have been revealed as a more effective method (see Section 3.3.3). With our settings, the yields of permanent cultivation (without any manuring) are much lower in the following years than in the first year after clearing, and vice versa, the workload is much higher than with slash-and-burn in the first year, when clearing is necessary. The yields for permanent cultivation without manuring are so low that further calculations make no sense, because the harvest will not suffice as seeds for the next year. The differences mainly depend on a different data base, concerning the workload of several methods and yields of permanent cultivation without manure.

It should be noted that Baum et al. [48] pursued calculations with a given size of field (0.5 ha), instead of identical yields. This is disadvantageous for slash-and-burn and results in a somewhat larger land consumption than it already has.

The main argument against slash-and-burn is the weed seeds found in archaeological crop samples (cf. Bogaard [2]). The weed data point to a great continuity of agriculture from the LBK onwards, with permanent fields and a good nutrition supply, maybe provided by the use of manure. But, is it adequate to completely reject slash-and-burn for the whole Neolithic? We think that, if there are other signs of burning the landscape, it is not adequate to do so.

Bogaard [2] completed a detailed investigation on Neolithic agriculture and weeds, and her work gives valuable insight into nutrient supply and soil disturbance. But, most of her samples are from LBK sites and only a few are from LN. She had to choose samples with at least 30 weed fragments, because clean crop samples cannot be used for correspondence analysis (or other ecological analysis of weed spectra). This might create a bias in the dataset. For slash-and-burn, no typical weeds are known because there are almost no weeds at all. There are LN crop stores that are rather clean (see for example Maier [45]), but other samples contain a few or many weed seeds and this suggests permanent fields. On the other hand, there could be a lot of weeds on the field, and nearly no seeds are found in the harvest (see Reynolds [49] for difficulties with the interpretation of weeds from crop samples and the usefulness of experimental data).

Although experiments can be useful for analyzing weed spectra (for example for reproducing different crop processing states), to assess weed spectra from experimental fields is very difficult, and we suggest that experiments are sometimes not the optimal method for investigating ancient weeds. This is mostly because "real life" conditions are missing on a scientific test field: there is no human activity besides the research work, no farm animals are around, and there is a "wrong" history of the immigration of species. For example, if someone establishes a three-field-rotation in a modern agricultural landscape, it will take a long time, or never occur, that typical weed species of former times will arrive on these fields. This is the reason why Bogaard [2] uses the FIBS (functional plant attributes) method, which makes interpretation independent from actual species composition. But there is another problem: most archaeobotanists agree that the plants found with the crops are the associated weeds. This is the most probable explanation. On the other hand, a large amount of the Neolithic weed species was also collected for eating and healing, and many of these species are widespread and frequent on more or less nutrient-rich soils, which not only includes arable fields, but also the villages and their surroundings. The remaining species are rare in the samples and normally come from habitats other than arable land (for example forests, clearings). There are very few "real" arable weed species (archaeophytes). These became more frequent after the onset of the BA and Iron Age, and are normally seen as indicators for a more extensive form of cultivation. For a real weed-phytocoenosis the Neolithic species composition seems somehow strange, for example Galeopsis tetrahit, Polygonum convolvulus, and Chenopodium album are not typical weeds for winter grain (they can occur there, in accordance to crop rotation, tillage, and density of crop stands, but are not really frequent and harmful). So, although 
care is taken to analyze samples which contain, most probably, weeds, no sample really shows "the field", and there remains a little uncertainty. On the other hand, the presence of annual weeds is a problem for the slash-and-burn theory and the question is, if they could enter a new field in the first year, why did they not on the experimental site. Weeds could enter a new field via unclean crop seed or via dispersal of plants growing in the surrounding area. Neolithic people gathered, and maybe promoted, edible species. Animals are vectors for the dispersal of seeds. Also, it is difficult to imagine the role of species that are disadvantageous as weeds, but useful for nutrition. Not only the weeds which are widespread, but also those which were only found occasionally and which were completely missing, are significant, and should be considered when contemplating a cultivation system.

Years of testing different methods in Forchtenberg showed that slash-and-burn works well, but that it is more difficult than expected to cultivate a field for more than one year, and impossible on given soils, without further measures. The production of manure from animal dung is a sophisticated method and has not been proven for the Neolithic. A new approach (Styring, et al. [50]) showed that charred crops from two LN sites at Lake Constance had medium to high $\delta^{15} \mathrm{~N}$ values higher than that of the wild plants consumed by herbivores on the site indicating $\mathrm{N}$-supply by manuring. Indeed the source of ${ }^{15} \mathrm{~N}$ cannot be proven by isotope analysis alone, but on the basis of comparable modern samples, Bogaard et al. [51] interpret their results as evidence for manuring. ${ }^{15} \mathrm{~N}$ values from crops grown with the slash-and-burn method were not investigated.

$\mathrm{N}$-supply could be produced by applying organic matter, or by fallow phases, during which grassland, shrub, or forest-organic matter is accumulated. Subsequently, a mobilization of the nutrients, making them plant-available, is necessary. This needs time and is favored by high temperatures, tillage, or other factors that support the microbiologic soil activity. Simple fertilization methods, such as the grazing of fallow land or the application of domestic litter, human faecal matter, or animal dung to nearby fields, are ideas that are not so devious, and will most likely cause an increase of yields, if the nutrient levels were previously low. The ability to achieve any further improvement in the soil and to obtain yet higher yield, becomes more and more difficult because a lot of manure needs to be produced and transported to the field. For subsistence farmers, a more extensive form of agriculture could be more suitable. This has not yet been tested, but is empirically the norm, because of the particular characteristics of cereal cultivation. That is why other agricultural crops (maize, pulses, potatoes, etc.) are regularly cultivated under intensive garden conditions, but not cereals. Assumptions about nutrient supply are issues in the current research, but manuring methods were beyond the scope of the Forchtenberg experiments. Experimental testing of applying manure would be interesting, but difficult, because cattle or goats have to be kept in the forest to produce authentic dung, and there are so many details that could be varied, that any approach would be disputable.

The conception of slash-and-burn versus permanent gardens is maybe too restrictive: Jacomet et al. wish to "bring together all types of palaeoenvironmental proxies in an integrative way", but in spite of this commendable approach, results of experiments and off-site data were challenged, rather than integrated. Nonetheless, they mention the idea that "fire could be used on a freshly cleared piece of land or ... some kind of in-field out-field system may have existed with most fields cultivated permanently and intensively in the vicinity of the villages and some out-fields occasionally prepared on burnt forest land." So, if there is evidence for permanent fields, but on the other hand, there is evidence for burning, why not ask whether both of these methods could complement one another? Bogaard et al. [52] assert that "high labour intensity ... limits the scale of production, and an alternative strategy is to increase absolute yields by expanding the scale of farming ('extensification'), with a corresponding decrease in intensity and area yields." Since there is no evidence for an extensification of LN agriculture at Lake Constance, slash-and-burn could be a method for compensating population changes, if an instantaneous expansion of permanent fields is not possible (lack of workforce, tools and supplies of work, or lack of optimal sites). Or, it could be the best method for new, poor, or badly organized inhabitants to gain ground. Permanent improvement of soils by manuring takes some time and regular manure input (Fraser, et al. [53]), whereas burning functions relatively quickly. 
Therefore, slash-and-burn could be a short-term strategy, to avoid complex soil preparation, whereas the manuring of permanent fields could be a long-term strategy, providing more stable conditions and demanding less land.

We recommend that slash-and-burn should be further considered as one possible method of land use and included in a comparison of different cultivation regimes (like e.g., Baum et al. 2016 did), and that Neolithic weed spectra should be used to investigate the details of cultivation, but not as discussion-ending argument respective slash-and-burn.

\section{Conclusions}

The results of the experimental slash-and-burn demonstrate that permanent cultivation was not possible without additional organic matter inputs. Therefore, agriculture in the Neolithic could have been maintained by slash-and-burn of new areas of the forest, or by the addition of organic matter to previously burned fields. Further experimental work at Forchtenberg could help to clarify the ways in which permanent cultivation on the same small plots of land could have been maintained.

The work input and risk of crop failure with the slash-and-burn practice is low, when compared to other agricultural systems. A disadvantage is the demand of space: to burn a certain area requires the fourfold area for the supply of small wood. After one cultivation period, a long-term fallow (ca. 12 years) is mandatory before cultivation can restart. This fallow/cropping ratio, of about three, is also known from other low-input farming systems worldwide (Scott et al. [54]). Assuming a fallow period of 12 years, and a burning and cultivation of a quarter of the area cleared per year, only about $3 \%$ of the total landscape could have been used for actual cultivation. The decrease of the Fagus curve at Lake Constance from 30\% to 5\% during the Younger Neolithic (Pfyn culture), can be interpreted as an indicator that all woodland dominated by Fagus was potentially arable land and was introduced into the cropping cycle, and consequently, large areas were under coppice of a different age. During this time, an increased population and the corresponding food demand had perhaps brought this agricultural system to its limits (Rösch [55]; Rösch, et al. [14]). In the transition phase to the Horgen culture, and in the early Horgen culture itself, a lower population and thus lower human impact, meant that the Fagus forest could recover. A second crisis during the Horgen culture was perhaps mastered by the development of a new land use system that needed less forest resources and allowed for higher population densities, but required more labor input.

The period of Neolithic slash-and-burn in temperate Europe lasted for perhaps two millennia and came to an end more than five millennia ago. Its traces in the soil are weak, and are not easy to detect and interpret. Nevertheless, an anthrom was created which determined the basic conditions for all kinds of land use, following the practice. Additionally, slash-and-burn practices did not disappear after this period, but have remained widespread in many forested landscapes across the globe, until now.

Acknowledgments: The project was founded by the DFG (German Research Coucil), the StollVITA-Stiftung, Waldshut, and the Stiftung WÜRTH, Künzelsau. The experimental area was given to our disposition by the Landesforstverwaltung Baden-Württemberg. Open access of this paper was enabled by Landesamt für Denkmalpflege im Regierungspräsidium Stuttgart. We thank three anonymous reviewers for helpful suggestions for improvement of the manuscript.

Author Contributions: Manfred Rösch and Otto Ehrmann conceived and designed the experiments; Harald Biester, Eileen Eckmeier, Renate Gerlach, Christoph Hartkopf-Fröder, Ludger Herrmann, Birgit Kury, Wolfram Schier, Erhard Schulz, Manfred Rösch and Otto Ehrmann performed the experiments; Manfred Rösch, Otto Ehrmann, Harald Biester, Arno Bogenrieder, Eileen Eckmeier, Renate Gerlach, Ludger Herrmann, Birgit Kury, Jutta Lechterbeck, Wolfram Schier and Erhard Schulz analyzed the data; Mathias Hall contributed reagents/materials/analysis tools; Manfred Rösch and Birgit Kury wrote the paper.

Conflicts of Interest: The authors declare no conflict of interest. The founding sponsors had no role in the design of the study; in the collection, analyses, or interpretation of data; in the writing of the manuscript, and in the decision to publish the results. 


\section{References}

1. Schier, W. Extensiver Brandfeldbau und die Ausbreitung der neolithischen Wirtschaftsweise in Mitteleuropa und Südskandinavien am Ende des 5. Jahrtausends v. Chr. Prähistorische Zeitschrift 2008, 84, 15-43. [CrossRef]

2. Bogaard, A. Neolithic Farming in Central Europe, An Archaeobotanical Study of Crop Husbandry Practices; Routledge: London, UK, 2004.

3. Childe, V.G. The Danube in Prehistory; Clarendon Press: Oxford, UK, 1929.

4. Boserup, E. The Conditions of Agricultural Growth: The Economics of Agrarian Change under Population Pressure; Allen \& Unwin: London, UK, 1965.

5. Sangmeister, E. Zum Charakter der bandkeramischen Siedlung. Ber RGK 1951, 33, 89-109.

6. Sangmeister, E. Die ersten Bauern. In Urgeschichte in Baden-Württemberg; Theiss: Stuttgart, Germany, 1983; pp. 429-471.

7. Soudský, B. The neolithic site of Bylany. Antiquity 1962, 36, 190-200. [CrossRef]

8. Iversen, J. Landnami Danmarks Steenalter; Danmarks Geologiske Undersøgelse: Kopenhagen, Denmark, 1941.

9. Iversen, J. The Influence of Prehistoric Man on Vegetation; Danmarks Geologiske Undersøgelse: Kopenhagen, Denmark, 1949.

10. Smith, R.W. The ecology of Neolithic farming systems as exemplified by the Avebury region. In Proceedings of the Prehistoric Society; Cambridge University Press: Cambridge, UK, 1984; pp. 143-157.

11. Steensberg, A. An Experiment in Stone Age Agriculture, Burning, Sowing and Harvesting; National Museum of Denmark: Copenhagen, Denmark, 1979.

12. Rowley-Conwy, P. Slashandburn in the temperate European Neolithic. In Farming Practice in British Prehistory; Edinburgh University Press: Edinburgh, UK, 1981; pp. 85-96.

13. Rösch, M. Zur Umwelt und Wirtschaft des Jungneolithikums am Bodensee-Botanische Untersuchungen in Bodman-Blissenhalde. Siedlungsarchäologische Untersuchungen im Bodenseeraum. ArchäolNachr Baden 1987, 38, $42-53$.

14. Rösch, M.; Kleinmann, A.; Lechterbeck, J.; Wick, L. Botanical off-site and on-site data as indicators of different land use systems: A discussion with examples from Southwest Germany. Veg. Hist. Archaeobot. 2014, 23, 121-133. [CrossRef]

15. Rösch, M. Anbauversuche zur (prä) historischen Landwirtschaft im Hohenloher Freilandmuseum Schwäbisch Hall-Wackershofen. In Experimentelle Archäologie in Deutschland; Isensee Verlag: Oldenburg, Germany, 1998; pp. 35-43.

16. Bauer, U. Die Entwicklung von Anbauverfahren im Ackerbau. In Experimentelle Archäologie in Deutschland, Bilanz 1997; Exar Corporation: Fremont, CA, USA, 1998; pp. 21-33.

17. Ministerium für Umwelt und Verkehr Baden-Württemberg. WaBoAWasser und Bodenatlas Baden-Württemberg; Ministerium für Umwelt und Verkehr Baden-Württemberg: Stuttgart, Germany, 2007.

18. Ehrmann, O.; Rösch, M.; Schier, W. Experimentelle Rekonstruktion eines jungneolithischen Wald-Feldbaus mit Feuereinsatz-Ein multidisziplinäres Forschungsprojekt zur Wirtschaftsarchäologie und Landschaftsökologie. Prähistorische Zeitschrift 2009, 84, 44-72. [CrossRef]

19. FAO. World Reference Base for Soil Resources 2006; FAO: Rome, Italy, 2016.

20. Herrmann, L. Bodenwissenschaftliche Untersuchungen im Forchtenbergprojekt—Böden, Standorteigenschaften, Nährstoff- und Wasserhaushalt. In Zu den Wurzeln Europäischer Kulturlandschaft-Experimentelle Forschungen; Materialhefte zur Archäologie, 73; Theiss: Stuttgart, Germany, 2005; pp. 83-100.

21. Schier, W.; Ehrmann, O.; Rösch, M.; Bogenrieder, A.; Hall, M.; Herrmann, L.; Schulz, E. The economics of Neolithic swidden cultivation: Results of an experimental long-term project in Forchtenberg (Baden-Württemberg, Germany). In Economic Archaeology: From Structure to Performance in European Archaeology; UPA: Bonn, Germany, 2013; pp. 97-108.

22. Mathieu, J.R.; Meyer, D.A. Comparing axe heads of stone, bronze, and steel: Studies in experimental archaeology. J. Field Archaeol. 1997, 24, 333-351. [CrossRef]

23. Schmithenner, H. Die Reutbergwirtschaft in Deutschland. Geographische Zeitschrift 1923, 29, 115-127.

24. Schneiter, F. Agrargeschichte der Brandwirtschaft. Forsch Geschichtl Landeskde Steiermark 25; Selbstverlag der historischen Landeskommission für die Steiermark: Graz, Austria, 1970.

25. Hafner, F. Mehrfachnutzung des Waldes. In Österreichs Wald-Vom Urwald zur Waldwirtschaft. Österreichischer Forstverein; Eigenverlag: Vienna, Austria, 1994; pp. 108-128. 
26. Ehrmann, O.; Rösch, M. Experimente zum neolithischen Wald-Feldbau in Forchtenberg: Einsatz und Auswirkungen des Feuers, Erträge und Probleme des Getreideanbaus. In Zu den Wurzeln Europäischer Kulturlandschaft-Experimentelle Forschungen; Materialhefte zur Archäologie, 73; Theiss: Stuttgart, Germany, 2005; pp. 109-140.

27. Aufhammer, G.; Simon, U. Die Samen landwirtschaftlicher Kulturpflanzen im Grundstein des ehemaligen Nürnberger Stadtheaters und ihre Keimfähigkeit. Zeitschrift $f$ Acker- und Pflanzenbau 1957, 103, 454-472.

28. Blume, H.P.; Deller, B.; Furtmann, K.; Leschber, R.; Paetz, A.; Wilke, B.M. Handbuch der Bodenuntersuchung; Beuth\&Wiley-VCH: Weinheim, Germany, 2013.

29. Ehrmann, O.; Biester, H.; Bogenrieder, A.; Rösch, M. Fifteen years of the Forchtenberg experiment-Results and implications for the understanding of Neolithic land use. Veg. Hist. Archaeobot. 2014, 23, 5-18. [CrossRef]

30. KTBL. Faustzahlen für die Landwirtschaft. 14; Auflage: Darmstadt, Germany, 2009.

31. Glaser, B.; Guggenberger, G.; Zech, W. Organic Chemistry studies on Amazonian dark earths. In Amazonian Dark Earths; Lehmann, J., Kern, D.C., Glaser, B., Woods, W.I., Eds.; Springer: Dordrecht, The Netherlands, 2003; pp. 227-241.

32. Herrmann, L.; Ehrmann, O.; Stein, C.; Wermbter, N.; Schulz, E.; Rösch, M.; Hall, M.; Bogenrieder, A.; Page, H.; Schier, W. The Forchtenberg Project-An Interdisciplinary experimental approach towards Neolithic Agriculture. Atti. Soc. Tosc. Sci. Nat. Mem. 2007, 112, 127-132.

33. Jacomet, S. Subsistenz und Landnutzung während des 3. Jahrtausends v. Chr. aufgrund von archäobotanischen Daten aus dem südwestlichen Mitteleuropa. In Umwelt Wirtschaft Siedlungen im Dritten Vorchristlichen Jahrtausend Mitteleuropas und Südskandinaviens; Wachholtz: Neumünster, Germany, 2008; pp. 355-378.

34. Rösch, M.; Ehrmann, O.; Kury, B.; Bogenrieder, A.; Herrmann, L.; Schier, W. Spätneolithische Landnutzung im nördlichen Alpenvorland: Beobachtungen Hypothesen Experimente. In Umwelt Wirtschaft Siedlungen im Dritten Vorchristlichen Jahrtausend Mitteleuropas und Südskandinaviens; Wachholtz: Neumünster, Germany, 2008; pp. 301-315.

35. Schulz, E.; Vannina, U.; Hall, M. The double mosaic-regeneration of vegetation and soil after clearing, burning, and cultivation: Lessons from the Forchtenberg experiment. Veg. His. Archaeobot. 2014, 23, 19-36. [CrossRef]

36. Eckmeier, E.; Rösch, M.; Ehrmann, O.; Schmidt, M.W.; Schier, W.; Gerlach, R. Conversion of biomass to charcoal and the carbon mass balance from a slash-and-burn experiment in a temperate deciduous forest. Holocene 2007, 17, 539-542. [CrossRef]

37. Mürle, R. Charakterisierung Organischer Bodensubstanz Entlang eines Klimagradienten Anhand Thermischer (Dsc-Tg) und Spektraler (Mirs-Drift) Methoden. Master's Thesis, University of Hohenheim, Stuttgart, Germany, 2013.

38. Menke, B. Vegetations- und Bodenentwicklung im Bereich der celticfields im Gehege Ausselbek bei Ülsby, Kreis Schleswig-Flensburg. Offa 1995, 52, 7-28.

39. Kirleis, W.; Fischer, E. Neolithic cultivation of tetraploid free threshing wheat in Denmark and Northern Germany: Implications for crop diversity and social dynamics of the Funnel beaker Culture. Veg. Hist. Archaeobot. 2014, 23, 81-96. [CrossRef]

40. Wilmanns, O.; Schwabe-Braun, A.; Emter, M. Struktur und Dynamik der Pflanzengesellschaften im Reutwaldgebiet des Mittleren Schwarzwaldes. Doc. Phytosociol. 1979, 4, 983-1024.

41. Pott, R. Vegetationsgeschichtliche und pflanzensoziologische Untersuchungen zur Niederwaldwirtschaft in Westfalen; Westfälisches Museum für Naturkunde: Münster, Germany, 1995.

42. Nolte, H.H. Geschichte Russlands; Reclam: Stuttgart, Germany, 1998.

43. Jääts, L.; Konsa, M.; Kihno, K.; Tomson, P. Fire Cultivation in Estonian Cultural Landscapes. In The Space of Culture-the Place of Nature in Estonia and Beyond; Tartu University Press: Tartu, Estonia, 2011; pp. 164-180.

44. Kreuz, A.; Märkle, T.; Marinova, E.; Rösch, M.; Schäfer, E.; Schamuhn, S.; Zerl, T. The Late Neolithic Michelsbergculture-just ramparts and ditches? A supraregional comparison of agricultural and environmental data. Praehistorische Zeitschrift 2014, 89, 72-115. [CrossRef]

45. Maier, U. Untersuchungen in der neolithischen Ufersiedlung Hornstaad-Hörnle IA am Bodensee. Forschungen und Berichte zur Vor-und Frühgeschichte in Baden-Württemberg 2001, 74, 9-384. 
46. Jacomet, S.; Ebersbach, R.; Akeret, O.; Antolin, F.; Baum, T.; Bogaard, A.; Brombacher, C.; Bleicher, N.K.; Heitz-Weniger, A.; Hüster-Plogmann, H.; et al. On-site data cast doubts on the hypothesis of shifting cultivation in the late Neolithic (c. 4300-2400 cal. BC): Landscape management as an alternative paradigm. Holocene 2016, 26, 1858-1874. [CrossRef]

47. Baum, T.G. Models of wetland settlement and associated land use in South-West Germany during the fourth millennium BC. Veg. Hist.Archaeobot. 2014, 3, 67-80. [CrossRef]

48. Baum, T.; Nendel, C.; Jacomet, S.; Colobran, M.; Ebersbach, R. "Slash and burn" or "weed and manure"? A modelling approach to explore hypotheses of late Neolithic crop cultivation in pre-alpine wetland sites. Veg. Hist. Archaeobot. 2016, 25, 611-627. [CrossRef]

49. Reynolds, P. Deadstock and livestock. In Farming Practice in British Prehistory; Edinburgh University Press: Edinburgh, UK, 1984; pp. 97-122.

50. Styring, A.; Maier, U.; Stephan, E.; Schlichtherle, H.; Bogaard, A. Cultivation of choice: New insights into farming practices at Neolithic lakeshore sites. Antiquity 2016, 90, 95-110. [CrossRef]

51. Bogaard, A.; Fraser, R.; Heaton, T.H.E.; Wallace, M.; Vaiglova, P.; Charles, M.; Jones, G.; Evershed, R.P.; Styring, A.K.; et al. Crop manuring and intensive land management by Europe's first farmers. Proc. Natl. Acad. Sci. USA 2013, 110, 12589-12594. [CrossRef] [PubMed]

52. Bogaard, A.; Hodgson, J.; Nitsch, E.; Jones, G.; Styring, A.; Diffey, C.; Tugay, O. Combining functional weed ecology and crop stable isotope ratios to identify cultivation intensity: A comparison of cereal production regimes in Haute Provence, France and Asturias, Spain. Veg. Hist. Archaeobot. 2016, 25, 57-73. [CrossRef] [PubMed]

53. Fraser, R.A.; Bogaard, A.; Heaton, T.; Charles, M.; Jones, G.; Christensen, B.T.; Styring, A.K. Manuring and stable nitrogen isotope ratios in cereals and pulses: Towards a new archaeobotanical approach to the inference of land use and dietary practices. J. Archaeol. Sci. 2011, 38, 2790-2804. [CrossRef]

54. Scott, A.C.; Bowman, D.M.; Bond, W.J.; Pyne, S.J.; Alexander, M.E. Fire on Earth: An Introduction; John Wiley \& Sons: Hoboken, NJ, USA, 2013.

55. Rösch, M. Agrarkrisen in der Vergangenheit: Ursachen, Verlauf, Bewältigung. Erklärungsversuche aus botanischer Sicht. In Strategien zum Überleben, Umweltkrisen und Ihre Bewältigung; RGZM-Tagungen 11: Mainz, Germany, 2011; pp. 81-94.

(C) 2017 by the authors; licensee MDPI, Basel, Switzerland. This article is an open access article distributed under the terms and conditions of the Creative Commons Attribution (CC BY) license (http:/ / creativecommons.org/licenses/by/4.0/). 